\title{
"The effect of longevity risks on the performance of stock market"
}

\begin{tabular}{|c|c|c|}
\hline AUTHORS & Hyung-Suk Choi & \\
\hline ARTICLE INFO & $\begin{array}{l}\text { Hyung-Suk Choi (2017). The eff } \\
\text { market. Investment Managemer } \\
\text { doi:10.21511/imfi.14(1-1).2017. }\end{array}$ & $\begin{array}{l}\text { s on the performance of stock } \\
\text { ovations, } 14(1-1), 173-180 \text {. }\end{array}$ \\
\hline DOI & http://dx.doi.org/10.21511/imfi.1 & \\
\hline RELEASED ON & Thursday, 27 April 2017 & \\
\hline RECEIVED ON & Monday, 06 February 2017 & \\
\hline ACCEPTED ON & Monday, 20 March 2017 & \\
\hline & \begin{tabular}{|l|}
$(c)) \overline{E Y}$ \\
\end{tabular} & \\
\hline LICENSE & $\begin{array}{l}\text { This work is licensed under a C } \\
\text { License }\end{array}$ & ttribution 4.0 International \\
\hline JOURNAL & "Investment Management and F & \\
\hline ISSN PRINT & $1810-4967$ & \\
\hline ISSN ONLINE & $1812-9358$ & \\
\hline PUBLISHER & LLC "Consulting Publishing Co & erspectives" \\
\hline FOUNDER & LLC "Consulting Publishing CoI & erspectives" \\
\hline & & ニニニ \\
\hline NUMBER OF REFERENCES & NUMBER OF FIGURES & NUMBER OF TABLES \\
\hline 10 & 5 & 4 \\
\hline
\end{tabular}

(c) The author(s) 2022. This publication is an open access article. 


\title{
Hyung-Suk Choi (Korea)
}

\section{The effect of longevity risks on the performance of stock market}

\begin{abstract}
In this study the author examines the effect of the speed of population aging on the financial markets in 11 OECD (The Organisation for Economic Co-operation and Development) countries after controlling the proportion of labor population, the growth rate of real GDP (Gross Domestic Product), the rate of increasing productivity, inflation rate, and the rate of increasing scale of pension market. The author finds that the performance of stock market is affected by complex factors including increasing of average life expectancy, the growth rate of real GDP, the rate of increasing productivity, the inflation rate, the earning rate of stock market and the rate of increasing scale of pension market. Especially, the proportion of economically active people is the most significant factor to explain the stock market performance. Considering the decreasing proportion of economically active people in aging societies, the decrease of productivity and eventually the decrease of earnings from financial markets would be expected.
\end{abstract}

Keywords: aging society, stock market performance, GDP growth, pension fund.

JEL Classification: G19, G23, J11.

Received on: $6^{\text {th }}$ of February, 2017.

Accepted on: $20^{\text {th }}$ of March, 2017.

\section{Introduction}

Over the last 30 years, developed countries such as OECD members have experienced a very strong growth of public pension systems to prepare the aging society and the growth is expected to get stronger in the future. Chand and Jaeger (1996) argue that the size of the public pension systems as a percentage of GDP will increase by about 50 percent from 1995 to 2030 in France and in Italy, and almost double in Germany, if benefits stay as they were in 1992 in real terms. In the early period of public pension system, the government would receive surplus to invest especially in the stock markets, but as the system matures the government needs money to pay for the benefit so that the government should sell their financial asset in the stock market. Thus, in addition to the numerous financial crises that affected the global financial markets, there would be another long-term change that could impact even more on the stock market.

Mitchell et al. (2006) reviewed the theoretical and empirical lessons regarding the potential impact of population aging on global financial markets and find that the onset of massive demographic change may have some undesirable impacts on key forms of private and public old-age support. Hári et al. (2008) analyzed the importance of longevity risk for the solvency of portfolios of pension annuities to

(C) Hyung-Suk Choi, 2017.

Hyung-Suk Choi, Ph.D. (Finance), Associate Professor, Faculty of Ewha School of Business, Ewha Womans University, Korea.

This work was supported by the National Research Foundation of Korea Grant funded by the Korean Government (NRF2013S1A5A2A03044404)

This is an Open Access article, distributed under the terms of the Creative Commons Attribution 4.0 International license, which permits unrestricted re-use, distribution, and reproduction in any medium, provided the original work is properly cited. show that if financial market risk is fully hedged so that uncertainty in future lifetime is the only source of uncertainty, pension funds are exposed to a substantial amount of risk. Boersch-Supan and Winter (2001) show that the growth rate of the pension fund industry in European countries is positively correlated with the size of the stock market.

A number of empirical studies have explored the relationship between a nation's population age structure and its capital market returns. Arnott and Chaves (2012) suggest that investors should prepare for a long prospective period during which returns will fall below their historical averages. Liu and Spiegel (2011) find a positive correlation between population age structure, particularly the fraction of the population of prime working age, and returns. Poterba (2001), however, does not find any robust relationship between age structure and equity returns in the United States, United Kingdom, or Canada.

Many countries including Korea have become aging societies rapidly, but the preparations for the aging society may not be adequate. Public pension plan has been controversial on its long-term sustainability, because instability of the pension finance has increased due to the rapidly progressive aging society and ensuring high profitability from pension structure. Especially in Korea, as government employee pension and military pension entered the mature stage, their pension payment exceeds pension premium more than $\$ 1$ billion every year, so that they should be compensated by the national finance for the loss. Given the amount of the fund's investment in the financial markets, the effect of becoming an aging society would be significant on the financial markets.

There is a prospect that there will be a great likelihood of changes in the financial markets. There 
are several important changes in financial market caused by the aging society. First, aging society converted many countries from having capital requirements to having financial surplus. If the capital is overly supplied due to the aging society, different from the past, there would be new demand for financial assets to meet the capital supplier's preference. This situation may cause considerable uncertainty and turbulence in financial market. Second, it expanded the range of financial transactions. In the past, when the aging society was not a big problem, there was no big demand for longterm asset except the demand for houses. The progression of aging society increases the demand for long-term financial assets. According to this transition, transactions at financial institutions are changing from mainly short-term asset management into harmonizing both long-term and short-term assets.

Moreover, aging society changes attitudes to riskiness and causes diversification of demand for financial products. This transition increases not only the preference for stable assets at financial markets, but also demand for innovative products at the same time. In this study, we examine how the demographic change and aging trend appear in OECD countries and what are the aging features that appear uniquely in those countries. Along with, it analyzes the impacts of demographic changes and economic changes on the stock market.

By examining the effect of the speed of population aging on the financial markets in 11 OECD countries after controlling the proportion of labor population, the growth rate of real GDP, the rate of increasing productivity, inflation rate, and the rate of increasing scale of pension market, we find that the performance of stock market is affected by complex factors including increasing of average life expectancy, the growth rate of real GDP, the rate of increasing productivity, the inflation rate, the earning rate of stock market and the rate of increasing scale of pension market. Especially, the proportion of economically active people is the most significant factor to explain the stock market performance. Considering the decreasing proportion of economically active people in aging societies, the decrease of productivity and eventually the decrease of earnings from financial markets would be expected.

The rest of this paper is organized as follows. Section 1 describes the data from the OECD database and other sources. Sections 2 and 3 describe the economic growth and the stock market performance in aging societies. In section 4, the empirical analysis and the results are reported. Finally, final section concludes.

\section{Data}

Over the last 30 years, we have experienced the very strong aging trend in OECD countries. In order to examine the effect of aging society on the financial markets, we selected 11 OECD member countries which have developed financial markets and reached the aging society. Aging society is a phenomenon that occurs when the median age of a country rises due to rising life expectancy and declining birth rates. Increase in the life expectancy leads to an aging society. Figure 1 shows a trend of the average life expectancy of the past 30 years in sample countries, from 1980 to 2015. In 1980, the life expectancies in most sample countries except Korea are around 70, but they grow over the last 35 years up to over 80 . Especially, the average life span of Korea is growing at a very fast rate compared to other countries, from 65.9 in 1980 to 81.9 in 2010. It is noteworthy that the growth of life expectancy in the United States is not severe relative to other OECD countries. Even in 2015, it is still less than 80 years.

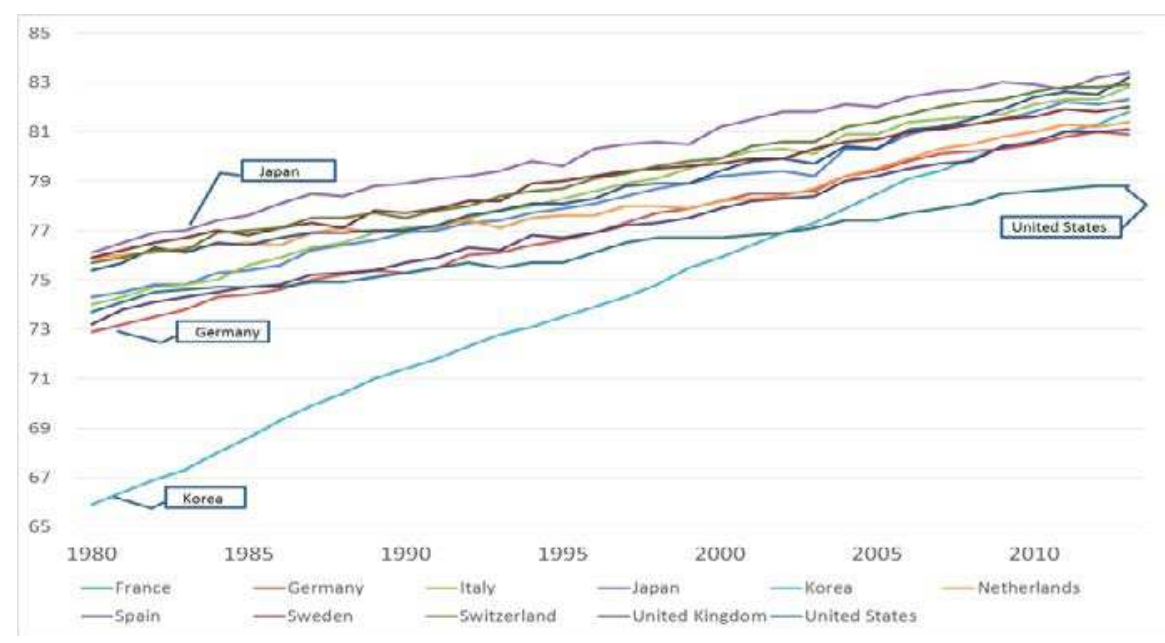

Source: OECD data and author's calculation.

Fig. 1. Life expectancy at birth 
Table 1 compares the pace of aging in major countries including Korea. According to the commonly-used United Nation's definition, any society whose proportion of the population aged 65 and over is greater than $7 \%, 14 \%$, or $20 \%$ is called "ageing society", "aged society", and "superaged society," respectively. France is the first country which entered the aging society, as the proportion of elderly population had exceeded $7 \%$ in 1864 . After that, the transition to an aged society and super-aged society is estimated to take 115 years and 39 years, respectively. Japan entered relatively late into the aging society among developed countries and it is estimated rapid transition to an aged society and super aged society that takes each 24 years and 12 years. However, although Korea had entered the aging society in 2000, it is expected to take place in 18 years to enter aged society and in 8 years from aged society to super aged society. In other words, despite the late entry into an aging society, it is expected to progress in aging at a faster rate than any other country. Depending on the aging progresses at a faster rate, support payments and the aging index are also expected to be world class soon.

Table 1. International aging rate comparison among developed countries

\begin{tabular}{|l|c|c|c|c|c|}
\hline \multirow{2}{*}{ Country } & \multicolumn{2}{|c|}{ Year entering the aging society } & \multicolumn{2}{c|}{$\begin{array}{c}\text { Years to reach } \\
\text { the aging society }\end{array}$} \\
\cline { 2 - 6 } & $\begin{array}{c}\text { Aging } \\
\text { society } \\
\text { (A) }\end{array}$ & $\begin{array}{c}\text { Aged } \\
\text { society } \\
\text { (B) }\end{array}$ & $\begin{array}{c}\text { Superaged } \\
\text { society } \\
\text { (C) }\end{array}$ & $\begin{array}{c}\text { (A) to } \\
\text { (B) }\end{array}$ & $\begin{array}{c}\text { (B) to } \\
\text { (C) }\end{array}$ \\
\hline France & 1864 & 1979 & 2017 & 115 & 39 \\
\hline $\begin{array}{l}\text { United } \\
\text { Kingdom }\end{array}$ & 1929 & 1976 & 2026 & 47 & 50 \\
\hline Germany & 1932 & 192 & 2009 & 40 & 37 \\
\hline $\begin{array}{l}\text { United States } \\
\text { America }\end{array}$ & 1942 & 2015 & 2036 & 73 & 21 \\
\hline Japan & 1970 & 1994 & 206 & 24 & 12 \\
\hline Korea & 2000 & 2018 & 2026 & 18 & 8 \\
\hline
\end{tabular}

Source: Korean Statistical Office and author's calculation.

\section{Economic growth in aging society}

Based on the growth accounting which is introduced by Solow (1957), many studies about the impact of aging society on economic growth expect that as the aging progresses, rate of economic growth declines (See, Feyrer (2007), Coulombe and Tremblay (2009), and De-huang and En-jun (2013)). The economic growth is determined by the input factors (labor and capital) and total factor productivity. Looking at it in more detail as shown in the following equation, the growth potential is determined by labor, capital and total factor productivity.

$Y=A \times f(L, K)$,

where $Y$ is the real GDP, $L$ is labor input, $K$ is the capital commitment, $A$ represents the total factor productivity, and $f($.$) means the production function.$ Therefore, economic growth increases when there is an increase in inputs such as labor, capital, and improvement on total factor productivity. However, it is concerned that as aging progresses, especially in decreasing labor input and labor productivity changing, the aging progress will slow down the potential for growth.

Looking specifically into the level of labor productivity, which is reported in Figure 2, Korean labor productivity in 2010 is about $30 \%$, which is the lowest level among 11 OECD countries. Increasing labor productivity rate is progressing throughout all over the industry. As a result, the IMF warned that Korea's potential growth rate would decline by $2 \%$ in 10 years. The decrease in the productive population and labor productivity growth rate due to the aging population reduces the potential growth rate. According to the results from CGE model, the average growth rate lowers steadily from $4.12 \%$ in $2006-10$ to $3.43 \%$ in $2011-20$, to $3.33 \%$ in $2021-30$, and to $2.64 \%$ in $2031-40^{1}$.

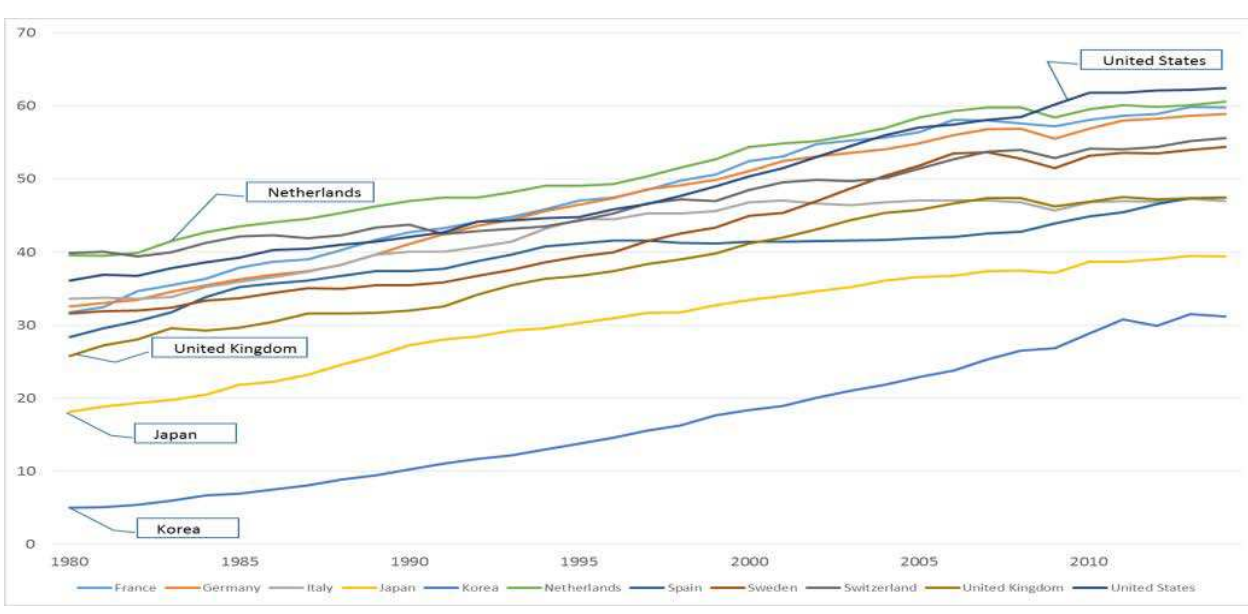

Source: OECD data and author's calculation.

Fig. 2. Labor productivity

\footnotetext{
${ }^{1}$ See IMF Annual Report (2013)
} 
To see the economic growth over the same period, we report the real GDP in 11 OECD countries in Figure 3. It is noteworthy that the GDP growth of the United States is consistently positive, except the global financial crisis around 2008. The GDP growth of other countries, however, seems to be weakened recently compared to the 1980s. The
GDP growth rate, which fell sharply in the 2000s, is the result of a complex action of aging and slowed growth rate of labor productivity, hours worked and the productive population. Coupled with the aging population, slowing economic growth is expected to be sustained. In Japan the reduced growth compared to 1980 s seems to be quite severe.

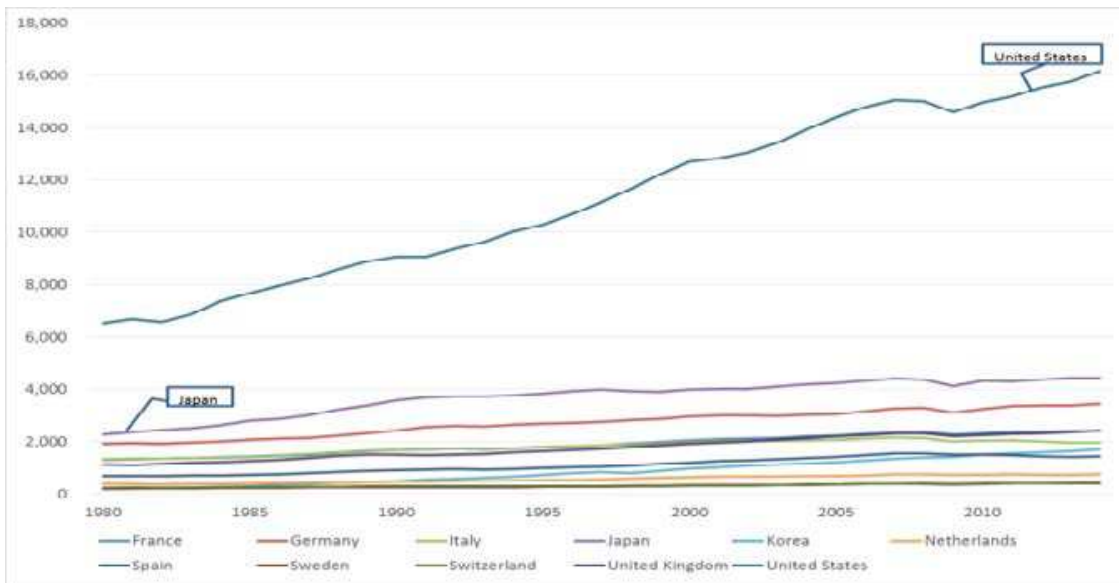

Source: OECD data and author's calculation.

Fig. 3. Real GDP (trillion US\$ in 2010)

\section{Stock market performance in aging society}

To examine the stock market performance in aging society, we plot the major stock market index in each sample country in Figure 4. It is noteworthy that Korea's stock market performance is low among OECD countries and the prospect is not bright by several factors including aging, slower economic growth. Aging effect on the overall growth of the financial markets can be explained largely divided due to the impact from the demand side and supply side. According to Siegel (1993), at the early stage of aging, financial sector is expanding due to increasing demand for financial assets, including pension savings. But as the aging progresses, there would be reduction in savings that makes overall reduction in demand for financial assets and accordingly asset prices will fall.
Furthermore, if the sustainability of current pension system is skeptical as people are concerned, as the aging society intensifies, falling asset prices phenomenon would appear and deepen. In other words, when the sum of pension payment appears likely to exceed the interest and dividend income arising from pension contributions and financial instruments, massive sale of financial instruments of pension contributions would occur to cover the cash outlays exceeding cash inflows and this will have negative effects on asset markets to collapse including declining asset prices, rising interest rates, and increasing capital costs. The asset meltdown theory is presented in a concern that the baby boomer generation retire and dispose of financial assets that they have accumulated make the asset price collapse and this provoked many reflections.

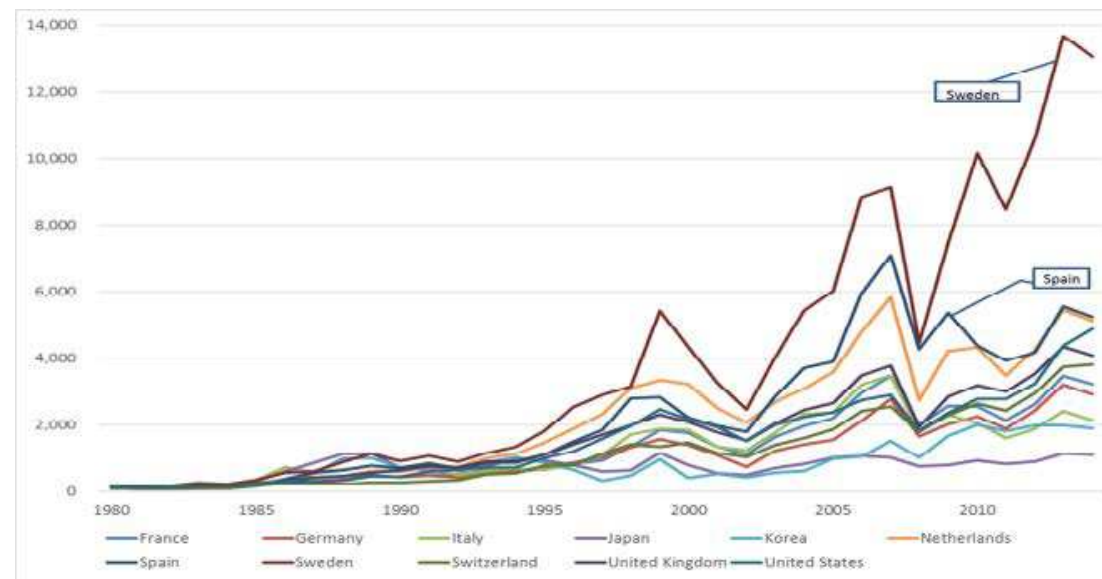

Source: World Federation of Exchanges and author's calculation.

Fig. 4. Stock market performance 
Aging phenomenon causes not only changes in demand to risks, but also to maturity. The more the aging phenomenon progresses, the more retired life becomes longer. Therefore, it prospects that a longterm financial product, which is needed to lead to a long-retired life is increasing demand. It prospects that the aging phenomenon leads to increase assets for long-term deposits the purpose of which is for an aged preparation, especially pension funds and installment funds. As reported in Figure 5, as almost all countries introduced various kinds of pension's savings schemes and adopted a policy that encourages long-term deposits through pension funds, the aging phenomenon seems to accompany a growth of various pension funds. The aging phenomenon affects not only the whole volume of financial market, but also the demand for various composition of commodities within the financial market. Generally, people tend to manage existing ones rather than trying something new as they are aging. This tendency is shown well in financial transaction, and as people get older, there is more conservative tendency of investment. Meanwhile the young have enough opportunities to recover even though they fail, the old do not have enough time to recover investment loss. Therefore, compared with the young, the elderly who do not have long remaining years tend to have high risk aversion attitudes and to prefer financial assets in order of stability, profitability and liquidity. Thus, it is expected that people prefer low-risk asset than highrisk, high-return asset, indirect investment than direct investment, and bond than stock.

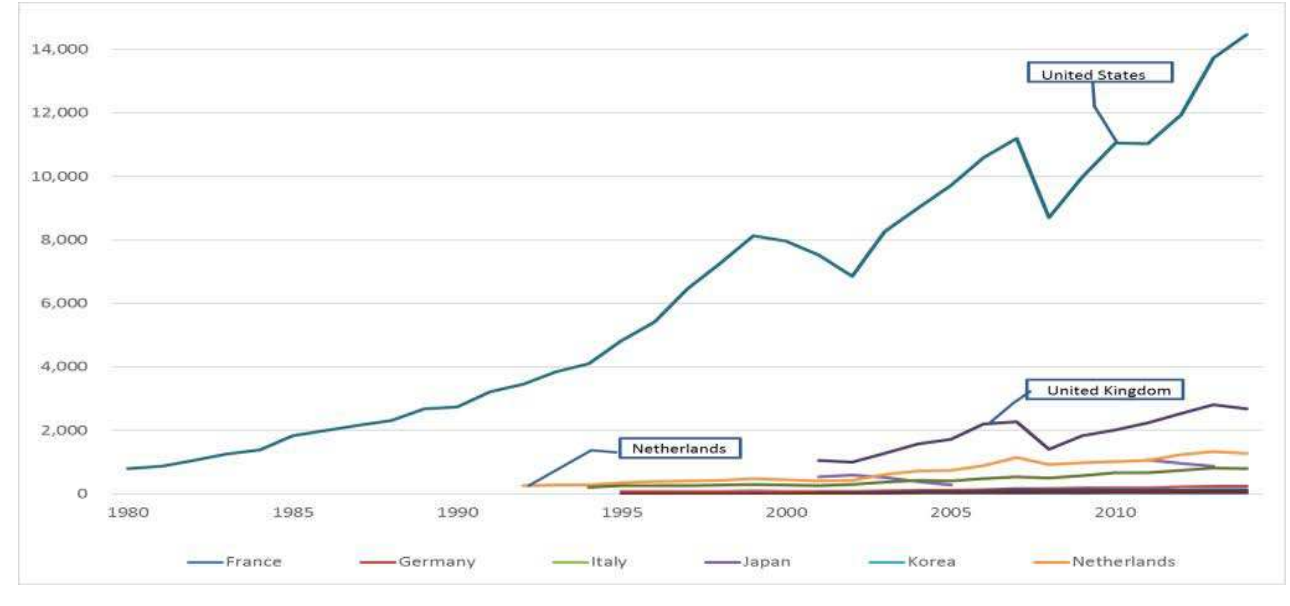

Source: OECD data and author's calculation.

Fig 5. Pension fund asset (billion US\$)

\section{Empirical analyses and results}

We analyzed the speed of population aging, the proportion of labor population, the growth rate of real GDP, the rate of increasing productivity, inflation rate, earning rate of stock market, the rate of increasing scale of pension market among 11 OECD countries. From these results, we report the average and the median among 8 variables of each country in Table 2. Compared with other countries, the age growth in Korea is 0.657 , which is more than double the growth in other countries on average. However, the proportion of labor population and the growth rate of real GDP seem outstanding compared with other countries so far.

Table 2. Descriptive statistics

\begin{tabular}{|c|c|c|c|c|c|c|c|c|c|}
\hline \multicolumn{2}{|c|}{ Country } & \multirow{2}{*}{$\begin{array}{c}\begin{array}{c}\text { Age } \\
\text { growth }\end{array} \\
0.311\end{array}$} & \multirow{2}{*}{$\begin{array}{c}\begin{array}{c}\text { Working } \\
\text { age } \\
\text { ratio }\end{array} \\
3.890\end{array}$} & \multirow{2}{*}{$\begin{array}{c}\begin{array}{c}\text { Real GDP } \\
\text { growth }\end{array} \\
1.852\end{array}$} & \multirow{2}{*}{$\begin{array}{c}\begin{array}{c}\text { Productivity } \\
\text { growth }\end{array} \\
1.948\end{array}$} & \multirow{2}{*}{$\begin{array}{c}\text { Inflation } \\
\text { rate }\end{array}$} & \multirow{2}{*}{$\begin{array}{c}\begin{array}{l}\text { Stock market } \\
\text { performance }\end{array} \\
1.101\end{array}$} & \multirow{2}{*}{$\begin{array}{c}\begin{array}{c}\text { Stock market } \\
\text { volatility }\end{array} \\
5.866\end{array}$} & \multirow{2}{*}{$\begin{array}{c}\begin{array}{c}\text { Pension asset } \\
\text { growth }\end{array} \\
59.010\end{array}$} \\
\hline & Mean & & & & & & & & \\
\hline riance & (median) & $(0.262)$ & (3.809) & $(1.966)$ & (2.079) & $(2.100)$ & (1.351) & $(5.503)$ & $(35.404)$ \\
\hline \multirow{2}{*}{ Germany } & Mean & 0.316 & 4.037 & 1.727 & 1.805 & 2.167 & 1.101 & 5.887 & 7.797 \\
\hline & (median) & $(0.269)$ & (3.854) & $(1.849)$ & $(1.933)$ & $(1.900)$ & (1.362) & $(5.642)$ & (7.457) \\
\hline \multirow{2}{*}{ Italy } & Mean & 0.341 & 3.730 & 1.212 & 1.052 & 4.967 & 0.929 & 7.020 & 15.502 \\
\hline & (median) & $(0.382)$ & (3.655) & $(1.560)$ & $(0.853)$ & $(3.300)$ & $(0.754)$ & $(6.923)$ & (17.004) \\
\hline \multirow{2}{*}{ Japan } & Mean & 0.278 & 4.282 & 2.075 & 2.390 & 0.806 & 0.746 & 5.843 & -12.384 \\
\hline & (median) & $(0.253)$ & $(4.150)$ & (1.942) & (2.258) & $(0.400)$ & $(0.761)$ & (5.622) & $(-11.002)$ \\
\hline \multirow{2}{*}{ Korea } & Mean & 0.657 & 9.863 & 6.758 & 5.772 & 4.676 & 1.086 & 7.255 & 24.415 \\
\hline & (median) & $(0.654)$ & $(10.152)$ & $(7.030)$ & $(5.797)$ & $(3.600)$ & (1.404) & $(6.420)$ & (25.997) \\
\hline \multirow{2}{*}{ Netherlands } & Mean & 0.213 & 4.604 & 2.090 & 1.279 & 2.321 & 1.165 & 5.395 & 9.041 \\
\hline & (median) & $(0.248)$ & (4.670) & $(2.160)$ & $(1.449)$ & $(2.300)$ & (1.408) & $(4.753)$ & (6.599) \\
\hline
\end{tabular}


Table 2 (cont.). Descriptive statistics

\begin{tabular}{|l|l|c|c|c|c|c|c|c|c|}
\hline \multicolumn{2}{|c|}{ Country } & $\begin{array}{c}\text { Age } \\
\text { growth }\end{array}$ & $\begin{array}{c}\text { Working } \\
\text { age } \\
\text { ratio }\end{array}$ & $\begin{array}{c}\text { Real GDP } \\
\text { growth }\end{array}$ & $\begin{array}{c}\text { Productivity } \\
\text { growth }\end{array}$ & $\begin{array}{c}\text { Inflation } \\
\text { rate }\end{array}$ & $\begin{array}{c}\text { Stock market } \\
\text { performance }\end{array}$ & $\begin{array}{c}\text { Stock market } \\
\text { volatility }\end{array}$ & $\begin{array}{c}\text { Pension asset } \\
\text { growth }\end{array}$ \\
\hline \multirow{3}{*}{ Spain } & Mean & 0.299 & 4.102 & 2.263 & 1.576 & 5.073 & 1.245 & 6.347 & 12.713 \\
\cline { 2 - 11 } & (median) & $(0.260)$ & $(3.916)$ & $(2.757)$ & $(1.188)$ & $(3.600)$ & $(1.520)$ & $(5.879)$ & $(12.157)$ \\
\hline \multirow{3}{*}{ Sweden } & mean & 0.235 & 3.332 & 2.084 & 1.648 & 3.591 & 1.462 & 6.870 & 11.070 \\
\cline { 2 - 11 } & (median) & $(0.251)$ & $(3.333)$ & $(2.559)$ & $(1.878)$ & $(2.400)$ & $(2.062)$ & $(6.488)$ & $(13.287)$ \\
\hline \multirow{3}{*}{ Switzerland } & mean & 0.276 & 4.087 & 1.755 & 1.000 & 1.867 & 1.062 & 4.733 & 7.981 \\
\cline { 2 - 11 } & (median) & $(0.253)$ & $(4.169)$ & $(1.769)$ & $(0.941)$ & $(1.100)$ & $(1.193)$ & $(4.512)$ & $(10.447)$ \\
\hline \multirow{2}{*}{$\begin{array}{l}\text { United } \\
\text { Kingdom }\end{array}$} & mean & 0.311 & 3.768 & 2.287 & 1.875 & 3.567 & 1.014 & 4.975 & 10.312 \\
\cline { 2 - 11 } & (median) & $(0.264)$ & $(3.733)$ & $(2.586)$ & $(1.875)$ & $(2.600)$ & $(1.318)$ & $(4.721)$ & $(10.963)$ \\
\hline \multirow{2}{*}{$\begin{array}{l}\text { United } \\
\text { States }\end{array}$} & mean & 0.203 & 4.753 & 2.728 & 1.668 & 3.212 & 0.988 & 4.141 & 9.469 \\
\cline { 2 - 10 } & (median) & $(0.257)$ & $(4.748)$ & $(2.807)$ & $(1.813)$ & $(3.000)$ & $(1.313)$ & $(4.020)$ & $(9.342)$ \\
\hline
\end{tabular}

Source: OECD data and author's calculation.

The proportion of labor population is $9.863 \%$, and it is higher than other countries' $3 \sim 4 \%$. Also, the growth rate of real GDP is $6.758 \%$, which is much higher than 2 3\%. However, other countries except for South Korea already have been proceeded the aging phenomenon, and South Korea has a high possibility that it would be the similar situation with other countries considering that the aging phenomenon of South Korea is progressing fast enough.

In Table 3, we report the correlation among variables based on references of 11 OECD countries above. From this result, we can realize that there is a meaningful relationship between the aging phenomenon and financial market. When we analyze the correlation among variables, working age ratio has a positive correlation in reality with the growth rate of real GDP and the increasing rate of productivity at significant level of $1 \%$. Additionally, there is a positive correlation between the growth rate of real GDP and the increasing rate of productivity. Following the aging phenomenon, it is shown when the scale of pension asset gets bigger, the scale of stock market has a positive correlation.

Table 3. Correlation

\begin{tabular}{|c|c|c|c|c|c|c|c|}
\hline & $\begin{array}{l}\text { Working } \\
\text { age ratio }\end{array}$ & $\begin{array}{l}\text { Real GDP } \\
\text { growth }\end{array}$ & $\begin{array}{l}\text { Productivity } \\
\text { growth }\end{array}$ & $\begin{array}{l}\text { Inflation } \\
\text { rate }\end{array}$ & $\begin{array}{l}\text { Stock market } \\
\text { performance }\end{array}$ & $\begin{array}{c}\text { Stock market } \\
\text { volatility }\end{array}$ & $\begin{array}{l}\text { Pension asset } \\
\text { growth }\end{array}$ \\
\hline Age growth & $0.384^{\star \star \star}$ & $0.234^{\star \star \star}$ & $0.330^{\star \star \star}$ & $0.108^{\star \star}$ & -0.020 & $0.095^{*}$ & $0.177^{\star \star}$ \\
\hline $\begin{array}{l}\text { Working } \\
\text { age ratio }\end{array}$ & & $0.624^{\star \star \star}$ & $0.653^{\star \star \star}$ & $0.245^{\star \star \star}$ & 0.061 & $0.142^{\star \star \star}$ & 0.055 \\
\hline $\begin{array}{l}\text { Real GDP } \\
\text { growth }\end{array}$ & & & $0.659^{\star \star \star}$ & 0.074 & 0.041 & $-0.113^{\star *}$ & 0.041 \\
\hline $\begin{array}{l}\text { Productivity } \\
\text { growth }\end{array}$ & & & & $0.147^{\star \star \star}$ & 0.046 & $0.087^{\star}$ & -0.009 \\
\hline Inflation rate & & & & & -0.074 & $0.184^{\star \star \star}$ & -0.042 \\
\hline $\begin{array}{l}\text { Stock market } \\
\text { performance }\end{array}$ & & & & & & $-0.099^{*}$ & $0.428^{\star \star \star}$ \\
\hline $\begin{array}{l}\text { Stock market } \\
\text { volatility }\end{array}$ & & & & & & & $-0.197^{\star \star}$ \\
\hline
\end{tabular}

Source: OECD data and author's calculation.

Note: $* * *, * *$, and $*$ indicate statistically significant at the $1 \%, 5 \%$, and $10 \%$ levels, respectively.

Ret $_{i t}=\alpha+\beta_{1}{\text { Age } \text { growth }_{i t}+\beta_{2} \text { Working age ratio }_{i t}+\beta_{3} \text { Re al GDP } \text { growth }_{i t}+\beta_{4} \text { Productivity growth }}_{i t}+$

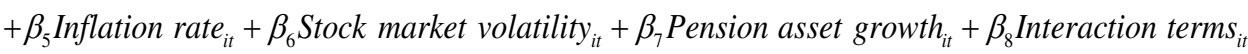

To examine the effect of aging society on the financial markets, we run the following regression model over the sample period between 1981 and 2014. We draw 6 models through panel analysis on the earning rate of stock market.

The regression results, as reported in Table 4, show that the earning rate of stock is affected by complex factors including increasing of average life expectancy, the growth rate of real GDP, the rate of increasing productivity, the inflation rate, the earning rate of stock market and the rate of increasing scale of pension market. Meaningful variables for all 6 models are a proportion of economically active people and an inflation rate. Overall, the earning rate of stock and the proportion of economically active people have $0.5 \sim 0.6$ betas, their correlation is high. Thus, we can draw that the 
higher the proportion of economically active people, the higher the earning rate of stock. After all, because of the aging phenomenon, the proportion of economically active people decreases dramatically. This leads to decrease of productivity and eventually links to decrease of the earning rate of stock.

Table 4. Regression results

\begin{tabular}{|c|c|c|c|c|c|c|}
\hline & Model 1 & Model 2 & Model 3 & Model 4 & Model 5 & Model 6 \\
\hline \multirow{2}{*}{ Intercept } & 0.210 & 0.378 & -0.015 & -0.864 & 0.017 & 0.129 \\
\hline & $(0.35)$ & $(0.21)$ & $(-0.01)$ & $(-0.47)$ & $(0.01)$ & $(0.09)$ \\
\hline \multirow{2}{*}{ Age growth } & -0.331 & 0.122 & 1.665 & 0.197 & 0.254 & 0.230 \\
\hline & $(-0.69)$ & $(0.26)$ & (1.71) & $(0.41)$ & $(0.54)$ & $(0.46)$ \\
\hline \multirow{2}{*}{ Working age ratio } & $0.437^{\star}$ & $0.654^{\star \star}$ & $0.623^{*}$ & $0.969 *$ & $0.580^{\star \star}$ & $0.527^{\star \star}$ \\
\hline & (2.04) & $(2.40)$ & $(1.98)$ & (3.14) & (2.44) & (2.27) \\
\hline \multirow{2}{*}{ Real GDP growth } & -0.078 & $-0.126^{\star}$ & $-0.136^{\star *}$ & $-0.091^{\star \star}$ & 0.155 & $-0.107^{\star}$ \\
\hline & $(-1.25)$ & $(-2.20)$ & $(-2.55)$ & $(-2.23)$ & (1.79) & $(-2.16)$ \\
\hline \multirow{2}{*}{ Productivity growth } & 0.094 & 0.009 & 0.023 & -0.061 & -0.018 & $0.224^{* *}$ \\
\hline & (1.81) & $(0.11)$ & $(0.29)$ & $(-0.71)$ & $(-0.30)$ & $(2.86)$ \\
\hline \multirow{2}{*}{ Inflation rate } & $-0.112^{* * *}$ & $-0.522^{*}$ & $-0.487^{\star \star}$ & $-0.554^{*}$ & $-0.480^{* *}$ & $-0.459^{* *}$ \\
\hline & $(-3.38)$ & $(-2.18)$ & $(-2.48)$ & $(-2.09)$ & $(-2.35)$ & $(-2.30)$ \\
\hline \multirow{2}{*}{ Stock market volatility } & -0.117 & $-0.275^{\star \star \star}$ & $-0.291^{\star \star \star}$ & $-0.267^{\star \star *}$ & $-0.272^{* * *}$ & $-0.250^{* \star \star *}$ \\
\hline & $(-1.30)$ & $(-3.46)$ & $(-3.41)$ & $(-3.55)$ & $(-3.52)$ & $(-3.29)$ \\
\hline \multirow{2}{*}{ Pension asset growth } & & $0.050^{\star \star}$ & $0.090^{\star \star \star}$ & $0.119^{*}$ & $0.085^{\star \star \star}$ & $0.081^{\star \star \star \star}$ \\
\hline & & (2.50) & (4.18) & $(2.12)$ & $(4.05)$ & (3.51) \\
\hline Pension asset growth & & & $-0.089^{* *}$ & & & \\
\hline${ }^{*}$ Age growth & & & $(-2.94)$ & & & \\
\hline Pension asset growth & & & & -0.017 & & \\
\hline${ }^{*}$ Working age ratio & & & & $(-1.58)$ & & \\
\hline Pension asset growth & & & & & $-0.016^{\star \star *}$ & \\
\hline${ }^{*}$ Real GDP growth & & & & & $(-3.90)$ & \\
\hline Pension asset growth & & & & & & $-0.016^{* *}$ \\
\hline * Productivity growth & & & & & & $(-2.90)$ \\
\hline Country fixed effects & Yes & Yes & Yes & Yes & Yes & Yes \\
\hline $\mathrm{N}$ & 341 & 142 & 142 & 142 & 142 & 142 \\
\hline Adj. R-squared & 0.015 & 0.386 & 0.441 & 0.381 & 0.430 & 0.417 \\
\hline
\end{tabular}

Source: OECD data and author's calculation.

Note: $* * *, * *$, and $*$ indicate statistically significant at the $1 \%, 5 \%$, and $10 \%$ levels, respectively.

\section{Conclusions}

In this study, we examined the effect of the speed of population aging on the financial markets in developed countries. We find that the aging phenomenon can bring depression of the financial market. The effect of the aging phenomenon to the overall growth of the financial market corresponds to the theory of the asset market collapse, which is the assumption that overall volume of financial market will be daunted. However, there are a lot of arguments against this. First, people argue that the volume of stock market never decreases dramatically considering the stock market itself only. Considering the structure of stock possession, few rich people own almost all stocks, but it is not seen that they would sell them suddenly for their old age life.

Also, even they sell their stocks, they would move to risk free asset, which guarantee comparative stable cash flow. Thus, the overall volume of the financial market would not be affected by this.
Thirdly, as mentioned above, if accumulated assets are not enough so far, it is necessary that there is a possibility that the rate of savings will increase. In other words, if an uncertainty on income after retirement increases, rather savings increase, so the demand on overall financial assets might grow as well. Lastly, it is necessary to consider asset mobility in open economy. Although domestic finances decrease according to the changes of population structure, there is a possibility that the demand on asset would increase because of influx of foreign assets in the opened financial market. Thus, there is an uncertainty regarding influences of the aging phenomenon on future circumstances, so several alternatives are needed embracing it. For example, according to "The role of finance in aging society," firstly, it is recommended to induce supply of various financial products to prepare the aging phenomenon including housing reverse mortgage, retirement pension, individual annuity insurance, guarantee trust system, long-term fund, health insurance and term insurance. 
In the longterm point of view, it is suggested to expand supply of long-term saving goods and to reinforce the institutional support, which enables to develop combined financial products linked to trust or insurance. Especially, it is necessary to pay attention when treasury inflation-protected securities are activated, they can be used as a useful way to understand the private expected inflation. Third, it is necessary to examine actively the introduction of longevity bond or longevity swap, which is able to hedge long-term risk, and it is covered by institutions, which pay life annuities such as national or private pension businesses such as insurance companies.

\section{References}

1. Arnott, R. D., \& Chaves, D. B. (2012). Demographic Changes, Financial Markets, and the Economy. Financial Analysts Journal, 68(1), 23-46.

2. Boersch-Supan, A. H., \& Winter, J. K. (2001). Population Aging, Savings Behavior and Capital Markets (No. w8561). National Bureau of Economic Research.

3. Coulombe, S., \& Tremblay, J. F. (2009). Education, Productivity and Economic Growth: A Selective Review of The Evidence. International Productivity Monitor, 18(3).

4. De-huang, L., \& En-jun, X. (2013, July). Research on Influence of Human Capital on The Economy Growth Based on the Extended Solow Model. In Management Science and Engineering (ICMSE), 2013 International Conference on (pp. 1460-1465). IEEE.

5. Feyrer, J. (2007). Demographics and productivity. The Review of Economics and Statistics, 89(1), 100-109.

6. Hári, N., De Waegenaere, A., Melenberg, B., \& Nijman, T. E. (2008). Longevity Risk in Portfolios of Pension Annuities. Insurance: Mathematics and Economics, 42(2), 505-519.

7. Liu, Z., \& Spiegel, M. M. (2011). Boomer Retirement: Headwinds for US Equity Markets? FRBSF Economic Letter, 2011, 26.

8. Mitchell, O. S., Piggott, J., Sherris, M., \& Yow, S. (2006). Financial Innovation for An Aging World (No. w12444). National Bureau of Economic Research.

9. Poterba, J. M. (2001). Demographic Structure and Asset Returns. Review of Economics and Statistics, 83(4), $565-584$

10. Solow, R. M. (1957). Technical Change and the Aggregate Production Function. The Review of Economics and Statistics, 312-320. 